\section{Jean Blackwell Hutson, 1914-1998}

David L. Easterbrook

Northwestern University

1997-98 Chair, Africana Librarians

Council

The Africana Librarians Council (ALC) remembers with great fondness Jean Blackwell Hutson, a regular participant in the work of the ALC and member of the ASA for many years.

Jean Hutson attended her first ALC meeting in 1959 and her participation in ALC activities continued until retirement. In addition to her contributions to the ongoing work of the ALC, Jean Huston is remembered by generations of researchers at the Schomburg Center for Research in Black Culture for the collections she built and the assistance she offered in their use.

A graduate of Barnard College (1935) and Columbia University Graduate School of Library Service (1936), Jean Hutson's career was devoted to the New York City Public Library System. From 1948 until 1980 she was first curator and then chief of the Schomburg Center for Research in Black Culture. She retired from the New York Public Library in 1984.

During her tenure, the collections at the Schomburg Center grew and its status as a major resource for research on Black history and culture became more widely known. Her focus on providing an adequate facility for the collections resulted in the 1981 opening of a new building that included space not only for the Schomburg Center's collections but also for research, exhibitions, and programming. Kwame Nkrumah, who had met Jean Hutson when he used the resources of the Schomburg Center, invited her to Ghana in 1964-65 to assist in the development of the African Collection at the University of Ghana. She established collection policies at the Balme Library that included materials about the diaspora as well as African studies. She remained professionally active during her retirement. For example, she served on the Task Force on Library and Information Services to Cultural Minorities of the National Commission on Libraries and Information Science in the 1980s.

Publications during her retirement include a chapter on the Schomburg Center in Black Bibliophiles and Collectors: Preservers of Black History (Washington: Howard University Press, 1990). The professional contributions of Jean Blackwell Hutson are discussed in detail in Glendora Johnson-Cooper's African American Historical Continuity: Jean Blackwell Hutson and the Schomburg Center for Research in Black Culture in Reclaiming the American Library Past: Writing the Women In edited by Suzanne Hildenbrand (Norwood: Ablex, 1996) 27-51.

In her statement accompanying her portrait in Brian Lanker's I Dream a World: Portraits of Black Women Who Changed America (New York: Stewart, Tabori and Chang, 1989), Jean Hutson reflected on the Schomburg Center: "One of the main things the Schomburg does is supply the ammunition for change. It is a part of the public library, open to everybody, everywhere. You don't have to be registered at the university to have access to the materials. The catalog is available all around the world. That has been and continues to be the opportunity that the Schomburg offers."

\section{ANNOUNCEMENTS}

Faculty Seminar In South Africa

-The Council on International Educational Exchange is pleased to offer "South Africa: New Directions in Nation-Building," an International Faculty Development Seminar to South Africa June 6-16, 1999. The seminar is designed for U.S. university faculty and administrators, in an effort to help stimulate initiatives toward internationalizing curricula. The seminar is hosted by the University of the Western Cape, located in Cape Town. In addition to lectures and discussions with South African academics and other experts in the communities, the seminar includes study tours related to the seminar theme. Site visits include: a tour of the townships of Cape Town (including Soweto, Langa, and Khayelitsha), a meeting with a representative of Parliament, and sitting in on a Truth and Reconciliation Commission forum. This 11-day seminar begins in Cape Town and ends in Pretoria. The seminar fee is $\$ 1,950$, which includes accommodations, lectures, site visits and study tours, orientation and farewell receptions, breakfast and lunch daily, airport transfers overseas (including an internal flight from Cape Town to Johannesburg), and international travel insurance. For further information, please contact Council's IFDS Department by telephone at (212) 822-2747, or by E-mail at ifds@ciee.org. You may also refer to our web site at <http://www.ciee.org/ifds>.

\section{Global Education}

The World Affairs Council of Boston is looking for Africans who are interested in sharing their culture with U.S. children in a one-time classroom visit. If interested, please contact: Silvi Llosa, Global Education Office, World Affairs Council of Boston, 617-482-1740

African Odyssey Interactive

-The Kennedy Center's African Odyssey Interactive Program has announced its Spring 1999 Chat Session Schedule. The following chat sessions will all take place from 12 Noon - 1 pm:

-April 2: Mark Wright on Revue Noire, Contemporary African Photography Mark Wright, A Curator at the Anacostia Museum and Center for African American History and Culture will discuss the contemporary African photographers whose work is being shown at the Revue Noire exhibit in the South Gallery from April 22 through May 22, 1999.

-May TBD: Souleymane Koly: Writer and Director of Mandingo opera Waramba Playwright / Director Soulcymane Koly will discuss his Mandingo opera Waramba, which will be scen in the Eisenhower Theater on May 4 and 5 . Time not yet determined.

-May 21: Mahen Bonetti: Director \& Creator of New York's African Film Festival

The New York African Film Festival is being coordinated in collaboration with the American Film Institute. The May 20 -23 festival will feature five different films from Cote D"Ivoire, Madagascar, Burkina Faso, and Zaire. Time not yet determined. 
-June 4: Brenda Randolph: Creator of African Children's Stories Online Brenda Randolph will join the sessions as an extension of Illuminations: African Writers on the World Stage, a series of readings by African Authors which will take place May 6-7 at the Kennedy Art Center.

\section{Arab Language Institute}

The National Council on U.S. Arab Relations offers: "Passage to Morocco," a three week language program at the Arab Language Institute in Fez, Morocco. The program consists of intensive Modern Standard Arabic study, cultural diversity exploration through home stays, lectures on Morocco and related North African issues and visits to historical and cultural attractions. For more information contact: The National Council on U.S. Arab Relations, Passage to Morocco Program Coordinator, 1140 Connecticut Avenue, NW Suite 1210, Washington, DC 20036. Telephone: (202)293-0801, Fax: (202) 293-0903.

African Language Manuscripts Sought. $\square$ Mother Tongue Editions is a nonprofit publishing organization whose purpose is to attempt to broaden its inventory of publications. An attempt is being made to locate original African language texts which may have been included in theses, books, or other academic publications and which might now be recycled for the purpose of producing monolingual reading material in a given African language. Please send manuscript to: Mother Tongue Editions, 511 Main Street, West Newbury, MA 01985. E-mail messages in this regard can be sent to John Hutchinson at hutch@bu.edu.

\section{NEH- "Writing Africa"}

The National Endowment for the Humanities and Central Michigan University announce an NEH Summer Seminar for School Teachers, Summer 1999: "Writing Africa: Chinua Achebe, Joyce Cary, Joseph Conrad, and Wole Soyinka." The institute will be held July 5 - August 6, 1999 (5 weeks), at Central Michigan University in Mount Pleasant, Michigan. For more information, contact: Maureen N. Eke, Central Michigan University, Dept. of English, Mt. Pleasant, MI 48859; (517) 774-2662 or (517) 774-3171; E-mail: maureen.n.eke@cmich.edu.
African Development Dissertation Workshop

The African Development Dissertation Workshop Program for 1998-1999 is designed for SubSaharan African students currently enrolled in doctoral programs in social, behavioral, natural, and biological sciences in the U.S. and Canada. Participants' expenses are fully covered by the university sponsoring the workshop, through a grant to the University of California, Berkeley, from the Rockefeller Foundation. Interested students are invited to apply directly to the host campus. General inquiries about the program may be directed to the Institute of International Studies, E-mail: iis@globetrotter.berkeley.edu. Please direct workshop specific questions to the contact listed with the host university. The topics, venue, and dates are as follows: Johns Hopkins University Baltimore, Maryland May, 1999: Health and Population Issues in Africa." Application deadline is April 30, 1999. For more information, contact: Dr. Henry Mosley, School of Hygiene and Public Health, The Johns Hopkins University, 615 North Wolfe Street, Baltimore, MD 21205-2179; email: hmosley@jhsph.edu.

Volunteer instructors, Nairobi, Kenya American Universities Preparation Institute (AUPI) in Nairobi, Kenya, is currently recruiting volunteer instructors. The volunteers will teach English and other secondary school subject area classes, while learning about Kenyan culture and studying Kiswahili. Candidates must possess a BA or BS. No prior teaching experience is needed, orientation and training takes place on site. For more information contact: Trina Gunn at aupi@bigfoot.com.

\section{Accés Cinéma Africain}

African Film Access announces three and nine-day programs beginning April 23, 1999 in Montréal, Québec (CANADA). African Film Access uses current films and video from Africa and the Caribbean both as documents for exploration and study and as a intensive French language program, within the context of a film festival. The three-day and nine-day programs that are offered include: unlimited film screenings, daily workshops and discussions with exhibiting filmmakers, daily French language classes, discussions with area specialists, music and dance performances and art exhibits, meals with filmmakers and lodging at the same hotel, and exploration of multicultural Montréal. For further information, call or write: Julia Schulz at Penobscot School, 28 Gay Street, Rockland, ME 04841 USA; Telephone: (207) 5941084; Fax: (207) 594-1067; e-mail: penobscot@midcoast.com; Web site: <http://www.cinemaafricain.org/>http: //www.cinemaafricain.org.

Travel Seminar to South Africa "South Africa after President Mandela," is the title of the seminar scheduled to take place June 19 - July 3, 1999. This seminar is sponsored by the Center for Global Education at Augsburg College. On the seminar, participants will explore many of the issues facing South Africa. The progress toward, and barriers to, development and reconstruction in a country ravaged by decades of apartheid rule. The style of the seminar is intensive and includes encounters with people and organizations representing many sectors of South Africa. For applications or more information about the seminar, call the Center for Global Education at (612) 330-1159 or 800-299-8889 or write: Center for Global Education, Augsburg College, 2211 Riverside Ave., Minneapolis, MN 55454. Application and deposit are due May 7, 1999.

Study Abroad

The Department of African American Studies at Eastern Michigan University announces the Intensive Educational and Cultural Program in South Africa, June 28 - July 30, 1999 (tentative dates). The program includes four weeks of intensive course-work and cultural excursions. The team will spend time at several universities in the country including the University of Transkei and the University of Cape Town. Dr. Victor Oguejiofor Okafor will lead the team. For more information contact: Office of Academic Programs Abroad, Eastern Michigan University, Ypsilanti, MI 48197; Toll free phone: 800-777-3541.

\section{AWARDS \& FELLOWSHIPS}

\footnotetext{
African Environmental History Research The University of Oxford invites applications for a post-graduate research studentship in African Environmental History. Preference may be given to applicants focusing on southern or central
} 